http://dx.doi.org/10.11646/phytotaxa.125.1.4

\title{
Twins are not alone: a recircumscription of Linnaea (Caprifoliaceae)
}

\author{
MAARTEN J.M. CHRISTENHUSZ \\ Jodrell Laboratory, Royal Botanic Gardens, Kew, Richmond, Surrey TW9 3DS, United Kingdom; E-mail: m.christenhusz@kew.org
}

\begin{abstract}
The genus Linnaea is reviewed and expanded to include the genera Abelia (excluding section Zabelia), Diabelia, Dipelta, Kolkwitzia and Vesalea, making it monophyletic and comprising 16 species. The history of the generic name is discussed. An updated description for the genus Linnaea is provided and new combinations or names for all taxa are provided in Linnaea.
\end{abstract}

Key words: botanical history, genus concepts, inflorescence structure

\section{Introduction}

Linnaea borealis Gronovius ex Linnaeus (1753: 631) was named in honour of Carolus Linnaeus to whom we owe the system of binomial nomenclature. The name was first coined by Dutch botanist Jan Frederik Gronovius (in Linnaeus 1737), because it was Linnaeus's favourite plant 'Planta nostra', which was later adopted by Linnaeus himself in his Species plantarum (1753). It is currently restricted to a single species, which may be considered unfortunate, because it honours such an important botanist. Ricket (1941) wrote that 'Linnaeus regarded it as his solemn duty to perpetuate the names of great botanists in generic names', and even though at the time it was argued that there often is no connection between the name and the botanist, 'there will be such charm in the association that it will never fade from memory'. Ricket (1941) provided the following example: 'Linnaea was named by the celebrated Gronovius and is a plant of Lapland, lowly, insignificant, disregarded, flowering but for a brief space-from Linnaeus who resembles it". This was of course meant ironically, but the name of Linnaeus was perpetuated in the name for the flower in several languages, and Linnaeus used the flower in his coat of arms after his knighthood and was frequently depicted with Linnaea.

Brown (1818) described some new plants in Abel Clarke's 'Narrative of a Journey in the Interior of China', where he named a particular ornamental shrub in honour of the traveller: Abelia Brown (1818: 376). Martens \& Galeotti (1843) described two species from Oaxaca, Mexico, which they placed in their new genus Vesalea Martens \& Galeotti (1843: 242), but they stated that the new genus has affinity with Brown's Abelia. Vatke (1872) proposed several Abelia species be treated in Linnaea, because of their similarity in flower structure. In his series of new plants from Asia, Maximowicz (1878) described the genus Dipelta Maximowicz (1878: 50), but among other Caprifoliaceae he observed similarities with Abelia. Dipelta was described on the basis of having two accrescent bracts beneath the flowers that become wing-like in fruit, but species of Abelia and Linnaea also have such bracts, although not always as conspicuous and not necessarily morphologically equivalent (Landrein \& Prenner 2013). When describing the new genus Kolkwitzia, Graebner (in Diels 1901: 593) pointed out that his new genus has clear morphological similarity to Linnaea, but was maintained separate from that genus on the basis of the fruit characteristics. In the same paper Graebner (in Diels 1901: 593) transferred many Abelia species to Linnaea, which was continued by Diels (1912). Wittrock (1907) focussed on the species Linnaea borealis, which he concluded was a polymorphic 
species in which he recognised over 200 forms based on foliar and floral characteristics. In spite of these efforts to enlarge Linnaea in the early $20^{\text {th }}$ Century, this was not followed in subsequent treatments, and Abelia became well established in floras and horticulture (e.g. Rehder 1911, Ohwi 1965, Villareal \& De la Rosa 2000, Cubey et al. 2013).

Phylogenetic studies of Caprifoliaceae s.l. and related families in Dipsacales have resulted in a much better understanding of generic relationships of the family (Pyck 2001, Bell et al. 2001, Winkworth et al. 2008, Landrein 2010a, Jacobs et al. 2010), and in particular those genera close to Linnaea (tribe Linnaeeae). In most studies, monophyly of the Linnaea clade was supported, although Zabelia (Rehder) Makino (1948: 175), traditionally included in Linnaeeae and sometimes considered to be a section of Abelia, was not found to belong there. The position of Zabelia was either suggested to be near Morina Linnaeus (1753: 28; Jacobs et al. 2010, 2011) or its position was not resolved (Landrein et al. 2012, Landrein \& Prenner 2013). Another genus associated with Linnaea in the past, because of some morphological similarity, is Heptacodium Rehder (1916: 617), but molecular results have shown that genus to be related to Lonicera Linnaeus (1753: 173) and its relatives (tribe Caprifolieae) (Jacobs et al. 2011). Landrein \& Prenner (2013) interpreted inflorescences of Heptacodium as intermediate between the tribes Linnaeeae and Caprifolieae.

In the Linnaea clade (excluding Heptacodium and Zabelia), the genus Abelia was polyphyletic: the Mexican species formed a clade (which can be treated as Vesalea) and two independent Asian clades. The clade including the type species, A. chinensis Brown (1818: 376), remained Abelia and the other clade was named Diabelia Landrein (2010b: 35). In all recent analyses (Jacobs et al. 2010, Landrein et al. 2012) the genera Abelia (excluding sect. Zabelia), Diabelia, Dipelta, Kolkwitzia, Linnaea and Vesalea form a single well-supported clade corresponding with tribe Linnaeeae.

\section{Discussion}

Creating new genera in order to maintain already existing genera in spite of overall morphological similarity among these clades appears to be a trend in some plant groups, with good examples in, for instance, grammitid ferns (Polypodiaceae), Ornithogalum Linnaeus (1753: 306; Asparagaceae), Potentilla Linnaeus (1753: 495; Rosaceae, see also Christenhusz \& Väre 2012), Streptocarpus Lindley (1828: t. 1173; Gesneriaceae, see also Christenhusz 2012) and many others. This process in the extreme would be creating a new genus for every species, which is frequently done in many groups of birds and mammals. One could easily make an argument in the opposite extreme, merging all clades into large genera without taking morphology into account. It seems to me that an intermediate approach is needed, bringing phylogenetic monophyly and morphology in harmony. This should in my opinion be supported by readily observable characters and be in line with other lineages in the family to be practical for the user. In the case of tribe Linnaeeae, related genera such as Lonicera of tribe Caprifolieae could be used as an example. The morphological diversity seen in Lonicera should prompt the question why that genus is not divided further, when Linnaea is. The morphological similarity of the genera in Linnaeeae, especially in characteristics of the flowers is so obvious that some of these species when first discovered, early botanists treated them as Linnaea, indicating a close relationship. Linnaea is easily recognised by its paired flowers, hence the vernacular name in English: twin flower. Linnaea in the broad sense are erect or creeping shrubs with simple usually opposite leaves without stipules. The inflorescences are paired cymes and reduced to 1 or 2 flowers per inflorescence with leaf-like or scale-like bracts. Flowers are bisexual, zygomorphic, the corolla tubular with 4 or 5 imbricate lobes and a nectary of glandular hairs inside the tube, and 4 stamens adnate to the corolla tube. The ovary is inferior, with axile placenta and single fertile ovules per locule, only 1 or 2 locules developing into an achene crowned with persistent (or deciduous) sepals. The most divergent species in the broader Linnaea are those currently placed in Kolkwitzia and Dipelta, for which I propose new combinations in Linnaea below. 
One argument of not accepting a broader circumscription of Linnaea, as proposed here, is the loss of genera well-known to horticulture, such as Abelia and Kolkwitzia, but the alternative is to divide one of these, Abelia, into three genera to produce a monophyletic classification, destabilising the names just as extensively and requiring new generic names to be adopted by the users. This also results in the Linnaea clade (see Landrein \& Prenner, 2013) consisting of six genera, none with more than three species, which is highly divided in comparison to other genera in Caprifoliaceae. The total number of species is only 13 according to Landrein (2010b), although other authors disagree about this (e.g Jacobs et al. 2010 included several additional species in their analysis that are not mentioned by Landrein 2010b). Here, I include a total of 17 taxa (following Yang \& Landrein 2011, excluding Zabelia). The taxonomy of the species complex surrounding L. uniflora (R.Br.) A.Br. \& Vatke in Vatke (1872:291) needs further study and may include as yet undescribed species.

The differences between the genera Abelia, Diabelia, Dipelta, Kolkwitzia, Linnaea and Vesalea lies in the inflorescence structure (Landrein et al. 2012, Landrein \& Prenner 2013), but without micromorphological study they all appear similar due to the strong reduction of the inflorescences. Inflorescence structure is variable within many other genera. Lonicera has a similar variability of inflorescence structure and also in plant habit (e.g. Laros 2013), even more diverse than Linnaea sensu lato. In several other groups this can also be found, with good examples in Amaryllidaceae: Milula spicata Prain (1895: 56; with racemose inflorescences) was found to be embedded in Allium (with umbellate inflorescences) and was hence transferred into that genus (Friesen et al. 2000). Additionally in Gilliesioideae of Amaryllidaceae, nomenclatural changes are needed to form monophyletic lineages irrespective of inflorescence structure (Fay et al. 2006). If inflorescence structure is the only reason to maintain separate genera, then these species are surely better placed in a single genus and the segregate genera reverted to subgeneric or sectional levels. Plant habit has also been applied as a character to separate some of genera, but there are also precedents for treating creeping, nearly herbacous species in the same genus as more typically woody shrubs or trees, such as in Betula Linnaeus (1753: 982; Betulaceae), Clematis Linnaeus (1753: 543; Ranunculaceae), Cornus Linnaeus (1753: 117; Cornaceae), Ficus Linnaeus (1753: 1059; Moraceae), Fuchsia Linnaeus (1753: 1191; Onagraceae), Lonicera (Caprifoliaceae) and Salix Linnaeus (1753: 1015; Salicaceae).

Because of these name changes, I realise that people working in horticulture will have to become familiar with the concept of Linnaea as a common garden shrub in the temperate zones of the world. That name will no longer be exclusive to the species $L$. borealis, which is only grown rarely in alpine plant collections. I should point out that a system of recognising six genera is not wrong per se-all genera are monophyletic and can be recognised morphologically (Landrein 2010a, Landrein \& Prenner 2013) — but that is not surprising because of the small number of species of which they consist. We can question if we are looking at differences between genera or species. Of course the delimitation of genera is arbitrary, and depends on tradition and preference of the user. Here, I am merely making the names available to provide a choice. It is up to users, ultimately, to decide what generic system is preferable and which names will be accepted in future treatments of Caprifoliaceae.

\section{Taxonomy}

\section{Linnaea [Gronov.] L.}

Gronovius in Linnaeus (1737: 188); Linnaeus (1753: 631).

Type: Linnaea borealis [Gronov.] L.

Synonyms: Abelia Brown (1818: 376), Diabelia Landrein (2010b: 35), Dipelta Maximowicz (1878: 50), Kolkwitzia Graebner in Diels (1901: 593), Linneusia Rafinesque (1830: 239), nom. illeg. superfl., Obolaria Kuntze (1891: 275), nom. illeg. hom. non Linnaeus (1753), Vesalea Martens \& Galeotti (1843: 242)

Erect or creeping shrubs. Leaves opposite or whorled, simple, without stipules, petiolate. Axillary buds exposed. Inflorescences terminal or axillary, simple or compound reduced thyrses, flowers single or paired. 
Bracts leaf-like or scale-like, located at bases of flowers, forming an epicalyx around the flowers. Flowers bisexual, zygomorphic. Perianth pentamerous. Calyx lobes 5, nearly free. Corolla funnelform or bilabiate with 5 spreading lobes that are imbricate in bud. Nectaries consisting of glandular hairs inside corolla tube. Stamens four, alternating the corolla lobes, filaments adnate with the lower $1 / 3-1 / 2$ corolla tube. Ovary inferior, 3-4-loculed with axile placentation, usually one or two locules with a single fertile ovule the other two with numerous sterile ovules. Styles long, terminated by white, capitate stigmas. Fruit an achene crowned with persistent or rarely deciduous sepals, with one or two seeds.

\section{Linnaea amabilis (Graebn.) Christenh., comb. nov.}

Basionym: Kolkwitzia amabilis Graebner in Diels (1901: 593).

Type: CHINA. Hua shan near Gniu yu, Giraldi 1725 (B).

Distribution: China (Anhui, Gansu, Henan, Hubei, Shaanxi, Shanxi); rare in the wild but widely cultivated in China, Japan, Europe and North America.

\section{Linnaea borealis Linnaeus (1753: 631).}

Lectotype (designated by Jonsell in Jarvis et al. 1993): Herb. Linn. no. 250 (LAPP!).

Heterotypic synonyms: Linnaea americana Forbes (1833: 135), L. borealis subsp. americana (J.Forbes) Hultén (1937: 310), L. borealis subsp. longiflora (Torr.) Piper \& Beattie (1915: 338), L. longiflora (Torr.) Howell (1900: 280), etc.. Note: A great number of additional synonyms are listed by Wittrock $(1907)$ and Brenner $(1908,1910)$, which are not repeated here to keep this paper concise. These synonyms should be addressed with respect to the variability of this species to be addressed in future studies.

Distribution: Circumboreal and subarctic (Canada, northern and central USA, Greenland, northern Britain, Fennoscandia, Baltic States, Mainland Europe south to the Alps, and the Balkans, Ukraine, Russia, Siberia, Kazakhstan, Mongolia, northern China, Korea, northern Japan).

\section{Linnaea chinensis (R.Br.) A.Braun \& Vatke (in Vatke 1872: 291).}

Basionym: Abelia chinensis Brown (1818: 376).

Type: CHINA. Guangdong: Lienchow River, 19 August 1887, C. Ford 1795 (BM!).

Heterotypic synonyms: Abelia aschersoniana (Graebn.) Rehder (1911: 127), A. cavaleriei Léveillé (1914: 60), A. hanceana M.Mart. ex Hance (1866: 216), A. ionandra Hayata (1918: 31), A. lipoensis An \& Gou (2009: 129), A. rupestris Lindley (1846: 63), Linnaea aschersoniana Graebner (1900: 139), L. rupestris (Lindl.) A.Braun \& Vatke in Vatke (1872: 291).

Distribution: China (Fujian, Guangdong, Guangxi, Guizhou, Hubei, Hunan, Jiangxi, Sichuan, Yunnan, Zhejiang), northern Vietnam, Taiwan. The species is commonly cultivated in China and Japan, occasionally so in Europe and North America.

4. Linnaea coriacea (Hemsl.) Christenh., comb. nov.

Basionym: Abelia coriacea Hemsley (1880: 53)

Type: MEXICO. San Luis Potosí: 6000-8000 feet, 1878, Parry \& Palmer 299 (holotype K!, isotypes GH, MO!). Homotypic synonym: Vesalea coriacea (Hemsl.) K.Tim \& B.Sun ex Landrein (2010: 38).

Distribution: Mexico (Nuevo León, San Luis Potosí).

\section{Linnaea dipelta Christenh., nom. nov.}

Replaced synonym: Dipelta floribunda Maximowicz (1878: 51), non Linnaea floribunda (M.Mart. \& Galeotti) A.Braun \& Vatke in Vatke (1872: 291).

Type: CHINA. 'Prov Shensi: montibus circa urbem Han-tschun-fu, initio Aprilis florens' 1875, Piasezki s.n. (LE)

Heterotypic synonym: Dipelta floribunda var. parviflora Rehder (1924: 241).

Distribution: China (Gansu, Guangxi, Hubei, Hunan, Shaanxi, Sichuan).

6. Linnaea elegans (Batalin) Christenh., comb. nov.

Basionym: Dipelta elegans Batalin (1895: 174)

Type: CHINA. 'Prov. Kansu orientale, trajectus altus inter pagus Mör ping et Wu ping', 27 June \& 5 July 1885, Potanin s.n. (LE).

Distribution: China (Gansu, Sichuan). 
7. Linnaea floribunda (M.Mart. \& Galeotti) A.Braun \& Vatke (in Vatke 1872: 291).

Basionym: Vesalea floribunda Martens \& Galeotti (1844: 242).

Type: MEXICO. Veracruz: Dans les forêts alpines du pic d'Orizaba a 10,000 pie. Galeotti 2641 (holotype BR)

Homotypic synonym: Abelia floribunda (M.Mart. \& Galeotti) Decaisne (1846: pl. IV).

Heterotypic synonyms: Abelia speciosa Decaisne (1846: sub pl. IV), Vesalea hirsuta Martens \& Galeotti (1844: 242).

Distribution: Mexico (Chiapas, Oaxaca, Puebla, Veracruz)

8. Linnaea forrestii Diels (1912: 178).

Type: CHINA. Yunnan: Salwin valley between Shichi-Ti and Xia-ku-ti, dry, scrubby hillsides, $6000-7000 \mathrm{ft}$, November 1905, Forrest 867 (holotype E-00265299!, isotype P-00482062!)

Homotypic synonym: Abelia forrestii (Diels) Smith (1916: 76).

Heterotypic synonyms: Abelia gracilenta Smith (1916: 76), A. microphylla (W.W.Sm.) Golubkova (1973: 241).

Distribution: south-central China (southwestern Sichuan, northwestern Yunnan)

9. Linnaea $\times$ grandiflora (André) Christenh., comb. nov.

Basionym: Abelia rupestris grandiflora André (1886: 488), without rank

Type: none cited, based on living plants cultivated by M. Rovelli [as 'Rivelli'] in Pallanza, Italy.

Homotypic synonym: Abelia $\times$ grandiflora (André) Rehder in Bailey (1900: 1).

Note: A garden hybrid of $L$. chinensis and $L$. uniflora, only known from cultivation.

10. Linnaea grandifolia (Villareal) Christenh., comb. nov.

Basionym: Abelia grandifolia Villareal in Villareal \& De la Rosa (2000: 174)

Type: MEXICO. Querétaro: Mun. Jalpan, 9-10 km al S de San Juan de Durán, Cerro Grande, laderas de bosque de pinoencino, 2600-2700 m, 13 June 1991, Servín 1101 (holotype IEB, isotype CAS).

Distribution: Central Mexico (Querétaro).

11. Linnaea mexicana (Villareal) Christenh., comb. nov.

Basionym: Abelia mexicana Villareal in Villareal \& De la Rosa (2000: 172).

Type: MEXICO. Oaxaca: Mun. San Sebastián Tecomaxtlahuaca, cerca de $10 \mathrm{~km}$ de San Sebastián Yecomaxtlahuaca, camino a San Martín Duraznos, $17^{\circ} 18^{\prime} \mathrm{N}, 9^{\circ} 06^{\prime} \mathrm{W}$, bosque de Quercus-Juniperus-Brahea, 1755 m, 19 July 1996, Calzada 21100 (holotype MEXU, isotypes ANSM, ENCB, L!).

Distribution: south-central Mexico (Oaxaca).

12. Linnaea occidentalis (Villareal) Christenh., comb. nov.

Basionym: Abelia occidentalis Villareal (1997: 84).

Type: MEXICO. Durango: Villarreal et al. 8180 (holotype: MEXU, isotypes ANSM, CIIDIR, ENCB, TEX).

Distribution: Mexico (Durango).

13. Linnaea serrata (Siebold \& Zucc.) Graebner (1900: 133)

Basionym: Abelia serrata Siebold \& Zuccarini (1835: 76)

Type: JAPAN. Honshu: Nagasaki. Mt. Sitsrama, Von Siebold s.n. (L!)

Homotypic sysnonym: Diabelia serrata (Siebold \& Zucc.) Landrein (2010: 37).

Heterotypic synonyms: Linnaea buchwaldii Graebner (1900: 136), Linnaea gymnocarpa Graebn. \& Buchw. ex Graebner (1900: 134).

Distribution: China (Zhejiang), Japan (Honshu, Kyushu, Shikoku).

14. Linnaea spathulata (Siebold \& Zucc.) Graebner (1900: 142)

Basionym: Abelia spathulata Siebold \& Zuccarini (1835 [-1839]: 77).

Type: JAPAN. Kiusiu: Mt. Innio, Von Siebold s.n. (L!)

Distribution: China (Zhejiang), Japan (Honshu, Kyushu, Shikoku).

Homotypic synonym: Diabelia spathulata (Siebold \& Zucc.) Landrein (2010: 37).

15. Linnaea tetrasepala (Koidz.) Christenh., comb. nov.

Basionym: Abelia spathulata var. tetrasepala Koidzumi (1915: 311)

Type: JAPAN. Honshu: Saitama-ken (Musashi, Chichibu), Matsumura s.n. (TI). 
Distribution: Japan (Honshu, Shikoku).

Homotypic synonyms: Diabelia tetrasepala (Koidz.) Landrein (2010: 36)

16. Linnaea uniflora (R.Br.) A.Br. \& Vatke in Vatke (1872: 291)

Basionym: Abelia uniflora Brown (1830: 15)

Type: CHINA. John Reeves.

Heterotypic synonyms: Abelia deutziifolia (H.Lév.) Léveillé (1914: 60), Abelia engleriana (Graebn.) Rehder (1911: 120), A. graebneriana Rehder (1911: 118), A. longituba Rehder (1911: 126), A. macrotera (Graebn. \& Buchw.) Rehder (1911: 126), A. mairei Léveillé (1915: 26), A. myrtilloides Rehder (1911: 120), A. parvifolia Hemsley in Forbes \& Hemsley (1888: 358), A. schischkinii Golubkova (1955: 394), A. schumannii (Graebn.) Rehder (1911: 121), A. tereticalyx (Graebn. \& Buchw.) Rehder (1911: 127), A. verticillata Léveillé (1914: 61), Linnaea engleriana Graebner (1900: 132), L. koehneana Graebner (1900: 132), L. macrotera Graebn. \& Buchw. in Graebner (1900: 131), L. parvifolia (Hemsl.) Graebner (1900: 129), L. schumannii Graebner (1900: 130), L. tereticalyx Graebn. \& Buchw. in Graebner (1900: 130), Strobilanthopsis deutziifolius Léveillé (1913: 21), S. hypericifolius Léveillé (1913: 20).

Note: This is a species complex that is not yet well resolved. Some taxa placed here in synonymy may, with further research, require recognition.

Distribution: China (Fujian, Gansu, Guangxi, Guizhou, Henan, Hubei, Hunan, Shaanxi, Sichuan, Yunnan). Frequently cultivated.

17. Linnaea yunnanensis (Franch.) Christenh., comb. nov.

Basionym: Dipelta yunnanensis Franchet (1891: 246, fig. 62).

Lectotype (designated here): CHINA. Yunnan: Les forêts au col de Yen tze hay (Lan kong), 3000 m, 27 June 1886, Delavay 2222 (P-00639763!).

Heterotypic synonyms: Dipelta ventricosa Hemsley (1908: 101).

Distribution: China (Gansu, Guizhou, Hubei, Shaanxi, Sichuan, Yunnan), and adjacent Burma.

\section{Unresolved name:}

Linnaea pseudoproterantha Pamp., Nuovo Giorn. Bot. Ital. 17: 723 (1910).

\section{Excluded names:}

Linnaea adenotricha (Hance) Graebn. = Zabelia biflora (Turcz.) Makino

Linnaea angustifolia (Bureau ex Franch.) Graebn. = Zabelia triflora (R.Br.) Makino

Linnaea brachystemon Diels $=$ Zabelia dielsii (Graebn.) Makino

Linnaea corymbosa Regel \& Schmalh. $\equiv$ Zabelia corymbosa (Regel \& Schmalh.) Makino

Linnaea dielsii Graebn. $\equiv$ Zabelia dielsii (Graebn.) Makino

Linnaea onkocarpa Graebn. $=$ Zabelia dielsii (Graebn.) Makino

Linnaea triflora (R.Br.) A.Braun \& Vatke $\equiv$ Zabelia triflora (R.Br.) Makino

Linnaea umbellata Graebn. \& Buchw. = Zabelia dielsii (Graebn. \& Buchw) Makino

Linnaea zanderi Graebn. = Zabelia dielsii (Graebn.) Makino

\section{References}

An, M.-T. \& Gou, G.-Q. (2009) Abelia lipoensis, a new species of the genus Abelia from Guizhou, China. Bulletin of Botanical Research (North-Eastern Forestry University) 29: 129-130.

André, E. (1886) Abelia rupestris grandiflora. Revue Horticole 58: 488.

Batalin, A. (1895) Notae de plantis asiaticis LXXII-LXXXIX. Trudy Imperatorskago S.-Peterburgskago Botanicheskago Sada 14: 165-184.

Bailey, L.H. (1900) Cyclopedia of American Horticulture. The Macmillan Company, New York.

Bell, C.D., Edwards, E.J., Kim, S.-T. \& Donoghue, M.J. (2001) Dipsacales phylogeny based on chloroplast DNA sequences. Harvard Papers in Botany 6: 481-499.

Brenner, M. (1908) Några Linnaea-former i Finland. Meddelanden af Societas pro Fauna et Flora Fennica 34: 89-97.

Brenner, M. (1910) Nya Linnaea-former från Ingå. Meddelanden af Societas pro Fauna et Flora Fennica 36: 9-13. 
Brown, R. (1818) Abelia. In: Clarke, A. (ed.) Narrative of a journey in the interior of China and of a voyage to and from that country in the years 1816 and 1817. Longman, Hurst, Rees, Orme \& Brown, London. pp. 376-378.

Brown, R. (1830) Abelia triflora. Plantae Asiaticae Rariores 1: 14-15.

Christenhusz, M.J.M. (2012) On African violets and Cape primroses-towards a monophyletic Streptocarpus (Gesneriaceae). Phytotaxa 46: 3-9.

Christenhusz, M.J.M. \& Väre, H. (2012) New combinations in Potentilla (Rosaceae) for the Nordic Flora. Phytotaxa 57: $1-5$.

Cubey, J., Armitage, J., Edwards, D., Lancaster, N. \& Whitehouse, C. (2013) RHS Plant Finder 2013. Royal Horticultural Society, Wisley.

Decaisne, J. (1846). Abelia floribunda, Abélie a fleurs nombreuses. Flore des serres et des jardins de l'Europe 2: pl. IV.

Diels, L. (1901) Die Flora von Central-China (Schluss). Botanische Jahrbücher für Systematik, Pflanzengeschichte und Pflanzengeographie 29: 577-659. http://dx.doi.org/10.1038/023263a0

Diels, L. (1912) Plantae Chinenses Forrestianae. Plants discovered and collected by George Forrest during his first expedition of Yunnan and Eastern Tibet in the years 1904, 1905, and 1905 - New and imperfectly known species. Notes from the Royal Botanic Garden, Edinburgh 5: 161-308.

Fay, M.F., Rudall, P.J. \& Chase, M.W. (2006) Molecular studies of subfamily Gilliesioideae (Alliaceae). Aliso 22: 367371.

Forbes, F.B. \& Hemsley, W.B. (1888) An enumeration of all the plants known from China Proper, Formosa, Hainan, Corea, the Luchu Archipelago, and the Island of Hongkong, together with their distribution and synonymy. Journal of the Linnean Society, Botany 23: 1-521. http://dx.doi.org/10.1111/j.1095-8339.1888.tb00535.x

Forbes, J. (1833) Hortus Woburnensis, a descriptive catalogue of upwards of six thousand ornamental plants cultivated at Woburn Abbey. London, James Ridgway. http://dx.doi.org/10.5962/bhl.title.59239

Franchet, A. (1891) Dipelta yunnanensis. Revue Horticole 63: 246-247.

Friesen, N., Fritsch, R.M., Pollner, S., \& Blattner, F.R. (2000) Molecular and morphological evidence for an origin of the aberrant genus Milula within Himalayan species of Allium (Alliaceae). Molecular Phylogenetics and Evolution 17: 209-218. http://dx.doi.org/10.1006/mpev.2000.0844

Golubkova, V.F. (1955) Generis Abeliae R. Br. species nova. Botanicheskie Materialy Gerbariia Botanicheskogo Instituta imeni V. L. Komarova Akademii Nauk SSSR 17: 394-398.

Golubkova, V.F. (1973) De speciebus nonnullis generis Abelia R. Br. (Caprifoliaceae Juss.). Novitates Systematicae Plantarum Vascularium (Novosti Sistematiki Vysshchikh Rastenii) 10: 241-248.

Graebner, P. (1900) Die Gattung Linnaea (einschliefslich Abelia). Botanische Jahrbücher für Systematik, Pflanzengeschichte und Pflanzengeographie 29: 120-145. http://dx.doi.org/10.1038/023263a0

Hance, H.F. (1866) Adversaria in stirpes imprimis Asiae orientalis critical minusve notas interjectis novarum plurimarum diagnosibus. Annales des Sciences Naturelles, Botanique, sér. 5, 5: 202-261.

Hayata, B. (1918) Icones plantarum formosanarum nec non et contributiones ad floram formosanam vol. 7. http://dx.doi.org/10.5962/bhl.title.1316

Hemsley, W.B. (1880) Diagnoses Plantarum Novarum vel Minus Cognitarum Mexicanarum et Centrali-Americanarum, part 3. Taylor \& Francis, London.

Hemsley, W.B. (1908) New or noteworthy plants - the genus Dipelta. The Gardeners' Chronicle ser. 3, 44: $101-103$.

Howell, T.J. (1900) A flora of Northwest America vol. 1. [no publisher given], Portland, Oregon.

Hultén, E. (1937) Flora of the Aleutian Islands and westernmost Alaska Peninsula: with notes on the flora of Commander Islands. J. Cramer, New York.

Jacobs , B., Pyck, N. \& Smets, E. (2010) Phylogeny of the Linnaea clade: are Abelia and Zabelia closely related? Molecular Phylogenetics and Evolution 57: 741-752. http://dx.doi.org/10.1016/j.ympev.2010.08.007

Jacobs, B., Geuten, K., Pyck, N., Huysmans, S., Jansen, S. \& Smets, E. (2011) Unraveling the phylogeny of Heptacodium and Zabelia (Caprifoliaceae): an interdisciplinary approach. Systematic Botany 36: $231-252$. http://dx.doi.org/10.1600/036364411x553306

Jarvis, C.E., Barrie, F.R., Allan, D.M. \& Reveal, J.L. (1993) A list of Linnaean generic names and their types. Regnum Vegetabile 127: 1-100.

Koidzumi, G. (1915) Decades Plantarum Novarum. The Botanical Magazine (Tokyo) 29(348): 311-315.

Kuntze, O. (1891) Revisio Generum Plantarum vol. 1. A. Felix, Leipzig.

Landrein, S. (2010a) Abelia and its relatives. The Plantsman (New Series) 9: 40-47.

Landrein, S. (2010b) Diabelia, a new genus of tripe Linnaeeae subtribe Linnaeinae (Caprifoliaceae). Phytotaxa 3: 34-38. 
http://dx.doi.org/10.11646/phytotaxa.3.1.4

Landrein, S., Prenner, G., Chase, M.W. \& Clarkson, J.J. (2012) Abelia and relatives: phylogenetics of Linnaeeae (Dipsacales-Caprifoliaceae s.l.) and a new interpretation of their inflorescence morphology. Botanical Journal of the Linnean Society 169: 692-713. http://dx.doi.org/10.1111/j.1095-8339.2012.01257.x

Landrein, S. \& Prenner, G. (2013) Unequal twins? Inflorescence evolution in the twinflower tribe Linnaeeae (Caprifoliaceae s.l.). International Journal of Plant Sciences 174: 200-233. http://dx.doi.org/10.1086/668251

Laros, A.J. (2013) Lonicera collection. Royal Boskoop Horticultural Society (KVBC). http:// http://www.lonicera.nl/. Accessed online 11 June 2013.

Léveillé, H. (1913) Decades plantarum novarum. CVI - CVIII. Acanthaceae chinenses et coreanae. Repertorium specierum novarum regni vegetabilis 12: 18-23. http://dx.doi.org/10.1002/fedr.4870120105

Léveillé, H. (1914) Flore du Kouy-Tchéou. Published by the author, Le Mans.

Léveillé, H. (1915) Catalogue des Plantes de Yun-Nan avec renvoi aux diagnoses originales, observations et descriptions d'espèces nouvelles. Published by the author, Le Mans.

Lindley, J. (1846) New plants, etc., from the Society's garden. Journal of the Horticultural Society of London 1: 61-77.

Linnaeus, C. (1737) Genera plantarum, ed. 1. Wishoff, Leiden.

Linnaeus, C. (1753) Species plantarum. L. Salvius, Stockholm.

Makino, T. (1948) Makinoa, sive plantae notae miscellaneae vol. 9. Published by the author, Tokyo.

Martens, M. \& Galeotti H. (1843) Enumeratio synoptica plantarum phanerogamicarum ab Henrico Galeotti in regionibus Mexicanis collectarum, Lonicerae. Bulletin de l'Academie Royale de Bruxelles 10: 241-242.

Martens, M. \& Galeotti H. (1844) Enumeratio synoptica plantarum phanerogamicarum in regionibus Mexicanis ab Henrico Galeotti collectarum (continuatio). Bulletin de l'Académie Royale des Sciences et Belles-Lettres de Bruxelles 11(1): 227-243.

Maximowicz, C.J. (1878) Diagnoses plantarum novarum asiaticarum. Bulletin de l'Academie Imperiale des Sciences de Saint-Pétersbourg Ser. 3, 24: 50-51.

Ohwi, M. (1965) Flora of Japan (in English). Smithsonian Institution, Washington, D.C.

Piper, C.V. \& Beattie, R.K. (1915) Flora of the Northwest Coast. The New Era Printing Company, Lancaster, Pennsylvania.

Prain, D. (1895) On Milula, a new genus of Liliaceae from the Eastern Himalaya. Scientific Memoirs by Officers of the Medical and Sanitary Department of the Government of India 9: 55-58.

Pyck, N. (2001) Phylogenetic relations within Dipsacales: a combined molecular and morphological approach. Thesis, Katholieke Universiteit Leuven, Louvain.

Rafinesque, C.S. (1830) Medical flora vol. 2. Atkinson \& Alexander, Philadelphia.

Rehder, A. (1911) Caprifoliaceae, Abelia, in Sargent, C.S. (ed.) Plantae Wilsonianae 1: 118 - 129.

Rehder, A. (1916) Caprifoliaceae, Heptacodium, in Sargent, C.S. (ed.) Plantae Wilsononianae 2: 617-619.

Rehder, A. (1924) New species, varieties and combinations from the herbarium and the collections of the Arnold Arboretum. Journal of the Arnold Arboretum 5: 235-242.

Ricket, H.W. (1941) Linnaeus' rules of nomenclature: a chapter in the history of plant names. Torreya 41: $188-191$.

Siebold, P.F. \& Zuccarini, J.G. (1835) Flora Japonica vol. 1. Published by the authors, Leiden.

Smith, W.W. (1916) Diagnoses specierum novarum in herbario Horti Regii Botanici Edinburgensis cognitarum CLICCL. Notes from the Royal Botanic Garden, Edinburgh 9: 71-144.

Vatke, W. (1872) Ueber die Gattung Abelia R. Br. Oesterreichische botanische Zeitschrift 22: 290-291. http://dx.doi.org/10.1007/bf01614741

Villareal, J.A. (1997) A new species of Abelia (Caprifoliaceae) from western Mexico, Brittonia 49: 84-86. http://dx.doi.org/10.2307/2807700

Villareal, J.A. \& De La Rosa I., M. (2000) Two new species of Abelia (Caprifoliaceae) from Mexico, Brittonia 52: 172176. http://dx.doi.org/10.2307/2666508

Winkworth, R.C., Lundberg, J. \& Donoghue, M.J. (2008) Toward a resolution of campanulid phylogeny, with special reference to the placement of Dipsacales. Taxon 57: 53-65.

Wittrock, V.B. (1907) Linnaea borealis L. species polymorpha et polychroma. Linnaea borealis L. en mångformig art. Acta Horti Bergiani 4(7): 5-178.

Yang, Q. \& Landrein, S. (2011) Linnaeaceae, in: Wu, Z.Y., Raven P.H. \& Hong, D.Y. (eds.) Flora of China 19: $642-648$. 